\title{
PENERAPAN MODEL LEARNING CYCLE 7E UNTUK MEMPREVENSI TERJADINYA MISKONSEPSI SISWA PADA KONSEP REAKSI REDOKS
}

\author{
Agus Sri Hono ${ }^{1)}$ \\ Leny Yuanita ${ }^{2)}$ \\ Suyono $^{3)}$ \\ ${ }^{1)}$ Guru Bidang Studi Kimia SMA Yayasan Pupuk Kaltim Bontang \\ ${ }^{2)}$ Dosen Prodi Pend. Sains PPs Universitas Negeri Surabaya \\ ${ }^{3}$ Dosen Prodi Pend. Sains PPs Universitas Negeri Surabaya \\ e-mail:a_srihono@yahoo.com
}

\begin{abstract}
Abstrak: Implementasi sebuah model solutif dengan model belajar Learning Cycle $7 E$ bertujuan untuk memprevensi (mencegah) terjadinya miskonsepsi siswa kelas X SMA khususnya pada konsep reaksi redoks. Subjek penelitian siswa kelas X-2, X-3, dan X-4 SMAN Model Terpadu Bojonegoro. Penelitian ini merupakan penelitian pra-eksperimen dengan one group pretest-postest design dengan tindakan pembelajaran prevensi miskonsepsi dengan menerapkan model Learning Cycle $7 E$ (Elicit, Engage, Explore, Explain, Elaborate, Evaluation, Extend). Identifikasi miskonsepsi menggunakan three tier diagnostic test. Variabel respon dalam penelitian ini adalah konsepsi dan hasil belajar siswa setelah dilakukan pembelajaran prevensi terjadinya miskonsepsi siswa dalam pembelajaran konsep redoks dengan menerapkan model Learning Cycle 7E. Teknik analisis data menggunakan analisis deskriptif dan analisis inferensial. Hasil penelitian menunjukkan pembelajaran prevensi miskonsepsi dengan menerapkan model Learning Cycle $7 E$ berhasil menambah proporsi siswa tahu konsep dan meningkatkan hasil belajar siswa pada konsep reaksi redoks.
\end{abstract}

Kata-kata Kunci: Miskonsepsi, Prevensi, Learning Cycle 7E

\begin{abstract}
Implementation a model of solution using $7 E$ Learning Cycle to prevent student's misconceptions in grade $X$ of Senior High School particularly on Redox Reaction concept. Research samples were grade X-2, X-3 and X-4 students of Integrated Model Senior High School in Bojonegoro. This study was pre-experiment study using One Group Pretest-Postest design. It was prevention learning of misconception by implementing $7 E$ Learning Cycle Model (Elicit, Engage, Explore, Explain, Elaborate, Evaluation, Extend). Identification of misconceptions used three-tier diagnostic test. Respon variables in this research were conception and student's achievement on Redox Reaction concept. Data analysis technique were descriptive and inferential analysis. Findings of this study show that prevention learning of misconception by implementing $7 E$ Learning Cycle Model increased student's proportion of 'knowing concept' and successfully student's achievement of Redox Reaction concept.
\end{abstract}

Keywords: Misconception, Prevention, 7 E Learning Cycle Model

\section{PENDAHULUAN}

Ilmu Kimia sebagai bagian dari sains berkaitan bagaimana memahami alam secara sistematis, sehingga diharapkan siswa mampu menguasai konsep-konsep kimia dengan baik, tanpa adanya miskonsepsi dalam pemikiran siswa. Mengacu pada Lampiran Permendiknas nomor 22 tahun 2006 (standar isi mata pelajaran kimia), salah satu tujuan mata pelajaran kimia di SMA/MA adalah memahami konsep, prinsip, hukum, dan teori kimia serta saling keterkaitannya dan penerapannya untuk menyelesaikan masalah dalam kehidupan seharihari dan teknologi, maka ada dua hal yang berkaitan dengan kimia yang tidak terpisahkan, yaitu kimia sebagai produk (pengetahuan kimia yang berupa fakta, konsep, prinsip, hukum, dan teori) temuan ilmuwan dan kimia sebagai proses, yaitu kerja ilmiah (Depdiknas, 2006). Simpulan, pembelajaran kimia dan penilaian hasil belajar kimia harus memperhatikan karakteristik ilmu kimia sebagai proses dan produk.

Berkaitan karakteristik ilmu kimia sebagai proses, menurut Amien (1988) proses pembelajaran akan berkembang baik jika keterlibatan siswa semakin besar. Prinsip psikologi menyatakan, apabila pada proses belajar keterlibatan siswa dalam kegiatan pembelajaran semakin besar, maka makin besar pula bagi siswa untuk mengalami proses belajar. Keterlibatan siswa yang besar dalam pembelajaran biasa disebut sebagai pembelajaran "student centered" atau pembelajaran yang berpusat pada siswa. Sesuai dengan lampiran permendiknas nomor 22 tahun 2006, bahwa pembelajaran yang berpusat pada siswa adalah pembelajaran dengan proses inkuiri ilmiah yang menekankan pada pemberian pengalaman belajar secara langsung melalui proses ilmiah. Pemahaman konsep yang baik pada diri siswa, tanpa adanya miskonsepsi merupakan harapan yang diinginkan setelah siswa banyak terlibat dalam pembelajaran.

Miskonsepsi adalah pemahaman konsep oleh siswa yang tidak sesuai dengan konsep yang benar menurut para ahli (Suparno, 2005). Menurut Hasan et al. (1999) miskonsepsi adalah pemahaman yang dimiliki seseorang dengan struktur kognitif yang berbeda dengan pemahaman yang diterima secara umum dan yang dianggap mengganggu perolehan pengetahuan baru. Definisi yang hampir sama, Nakhleh (1992) bahwa miskonsepsi adalah setiap konsep yang berbeda dari pemahaman ilmiah yang diterima secara umum, dan menurut Ibrahim (2012) miskonsepsi adalah konsepsi yang dimiliki oleh seseorang yang jelas-jelas berbeda 
bahkan seringkali berbeda dengan konsep ilmiah. Simpulannya, miskonsepsi adalah konsepsi yang dimiliki siswa yang bertentangan dengan konsep ilmiah dan yang dianggap menggangu perolehan pengetahuan baru.

Miskonsepsi siswa sering ditemukan ketika siswa mempelajari ilmu kimia karena salah satu karakteristik ilmu kimia terdiri atas konsep-konsep yang bersifat abstrak. Penelitian yang mengungkap terjadinya miskonsepsi dalam pembelajaran kimia antara lain: Wahyuningrum dan Suyono (2013) menemukan miskonsepsi siswa pada pokok bahasan struktur atom dan SPU dan Yunianingsih dan Suyono (2013) menemukan miskonsepsi siswa pada pembelajaran ikatan kimia. Konsep-konsep struktur atom, sistem periodik unsur, dan ikatan ikatan kimia merupakan bagian dari konsep prasyarat yang harus dikuasai siswa sebelum mempelajari konsep redoks, maka kemungkinan besar ditemukan juga miskonsepsi siswa di dalam pembelajaran reaksi redoks. Sehubungan banyak keterkaitan konsep redoks dengan konsep-konsep kimia yang dipelajari siswa di kelas berikutnya, maka peneliti sengaja melakukan penelitian kemungkinan adanya miskonsepsi siswa pada pokok bahasan reaksi redoks. Kemungkinan adanya miskonsepsi siswa pada konsep reaksi redoks diidentifikasi dengan three tier diagnostic test.

Menurut Gagne et al. (1988) bahwa kesulitan dalam pemahaman konsep prasyarat akan berpengaruh pada pemahaman konsep berikutnya, sesuai dengan Teori Learning Hierarchy, sebagai contoh untuk menentukan bilangan oksidasi suatu unsur, siswa harus bisa membedakan ciri-ciri molekul senyawa, molekul unsur, ion, dan unsur. Sesuai dengan Lampiran Permendiknas nomor 22 tahun 2006, substansi materi kimia telah disusun sedemikian rupa sehingga konsep yang diajarkan lebih awal berfungsi sebagai konsep prasyarat pada konsep berikutnya. Konsep prasyarat pada reaksi redoks antara lain struktur atom, sistem periodik unsur dan ikatan kimia, sehingga dengan pemahaman siswa terhadap konsep prasyarat tersebut diharapkan memperkuat pemahaman terhadap konsep reaksi redoks.

Berdasarkan pengertian miskonsepsi yang berarti konsepsi siswa yang bertentangan dengan konsep ilmiah, maka miskonsepsi dimungkinkan dapat dicegah dengan pembelajaran yang mengajarkan metode-metode ilmiah dalam memperoleh pengetahuan baru, yaitu pembelajaran dengan model Learning Cycle 7E. Model ini memberikan kesempatan kepada siswa untuk belajar secara langsung berhadapan dengan objek melalui fase ekspolarasi dalam pembelajaran. Model Learning Cycle 7E merupakan hasil penyempurnaan dari Learning Cycle 5E, yang diadaptasi dari Eisenkraf (2003). Learning Cycle 7E mempunyai 7 sintaks yang penting yaitu: (1) Elicit (mendatangkan pengetahuan awal siswa). (2) Engage (mengajak), (3)
Explore (eksplorasi), (4) Explain (menjelaskan), (5) Elaborate (menerapkan), (6) Evaluate (mengevaluasi), dan (7) Extend (memperluas).

Pembelajaran dengan learning cycle merupakan pembelajaran berbasis penyelidikan yang bertujuan untuk meningkatkan kualitas pembelajaran, memberikan siswa dengan pengalaman ilmu yang lebih otentik seperti layaknya seorang ilmuwan sesuai dengan sifat ilmu dan dapat mendorong pemahaman konsep siswa (Turkmen, 2006). Polyiem et al. (2011) memperoleh temuan bahwa dengan menggunakan Learning Cycle $7 \mathrm{E}$ berhasil meningkatkan hasil belajar dan mengembangkan keterampilan berpikir, serta daya nalar siswa. Peneliti yang lain Sumarni (2010) berhasil memprevensi miskonsepsi mahasiswa melalui 3siklus pembelajaran dengan menerapkan model learning cycle.

Berdasarkan latar belakang tersebut, maka peneliti akan melakukan penelitian tentang penerapan model Learning Cycle 7E untuk memprevensi terjadinya miskonsepsi siswa pada pokok bahasan reaksi redoks.

Tujuan utama dari penelitian ini adalah mengimplementasikan sebuah model solutif untuk mengatasi miskonsepsi dengan cara mencegah miskonsepsi siswa kelas X SMA khususnya pada konsep reaksi redoks.

\section{METODE PENELITIAN}

Penelitian ini merupakan sebuah tindakan pencegahan miskonsepsi siswa pada konsep reaksi redoks. Rancangan penelitian yaitu pra-eksperimen jenis one group pretest-posttest design. Penelitian ini dimulai dengan melakukan tes awal (pre-test) yang digunakan untuk mengetahui prakonsepsi siswa dan pembentukan kelompok kooperatif siswa di kelas. Penelitian dilanjutkan dengan pembelajaran model Learning Cycle 7E dengan materi reaksi redoks. Sesudah pembelajaran prevensi dilakukan post-test I untuk memetakan konsepsi siswa sesudah pembelajaran dengan model Learning Cycle 7E dan mengetahui hasil belajar siswa pada konsep reaksi redoks. Terkait pemetaan konsepsi siswa, berdasarkan hasil post-test I dilakukan pengelompokan konsepsi siswa yang meliputi tahu konsep (TK), tidak tahu konsep (TTK, dan miskonsepsi (MK1, MK2, dan MK3) berdasarkan respon jawaban siswa pada three tier diagnostics test seperti yang disarankan oleh Arslan et al.(2012).

Sasaran penelitian adalah siswa kelas X2, X-3, dan X-4. Teknik pengumpulan data yang dilakukan sebagai berikut: (1) Pengamatan, digunakan untuk menilai keterlaksanaan pembelajaran sesuai dengan sintaks yang telah dirancang oleh guru dalam RPP, menilai kompetensi psikomotorik dan afektif siswa, (2) Tes Pemahaman Konsep, dilakukan dalam dua tahap yaitu tes awal (pretest), diberikan sebelum kegiatan belajar mengajar 
pertemuan pertama dan post-test I untuk memperoleh data konsepsi dan hasil belajar siswa setelah tindakan prevensi dengan menerapkan model pembelajaran Learning Cycle 7E, (3) Kuesioner, digunakan untuk mengidentifikasi faktor-faktor penyebab terjadinya miskonsepsi pada siswa setelah diberikan post-test I.

Konsepsi siswa dianalisis secara deskriptif dan hasil belajar siswa, selain dianalisis secara deskriptif juga menggunakan statistik untuk membuat simpulan yang berlaku umum. Pengolahan data secara statistik dilakukan dengan menggunakan program SPSS (Statistical Package for Social Science) versi 18.0. Uji statistik yang digunakan dalam penelitian ini, yaitu: Mann-Whitney Test, Kruskal Wallis Test, Kolmogorov-Smirnov Test dan $t$-Test dengan uji satu sampel.

\section{HASIL DAN PEMBAHASAN}

\section{A. Prakonsepsi Siswa Sebelum Prevensi Miskonsepsi Siswa}

Tujuh buah konsep reaksi redoks yang tersebar dalam 21 butir soal yang dikerjakan siswa, semua berpotensi menyebabkan MK, namun yang terbesar pada konsep reaksi redoks ditinjau dari perubahan elektron. Konsep yang lain yang berpotensi menyebabkan terjadinya MK adalah bilangan oksidasi, reaksi redoks ditinjau dari bilangan oksidasi, dan tata nama senyawa anorganik menurut tinjauan bilangan oksidasi. Istilah bilangan oksidasi memang belum pernah dipelajari secara formal di sekolah. Apalagi istilah tersebut tidak tampak dalam suatu unsur, ion, atau senyawa, namun dalam menentukannya perlu dihitung dengan mengikuti aturan tertentu, dan terkait dengan konsep-konsep yang lain. Karakteristik siswa yang berlaku pada kelas X-2, tidak persis sama dengan siswa kelas X-3 dan X-4, namun ada beberapa yang mirip, yaitu prakonsepsi siswa yang berupa TTK dominan pada semua konsep yang diujikan.

Merupakan gambaran yang wajar, profil prakonsepsi siswa pada ketiga kelas tersebut dominan pada status TTK, hal ini memberikan gambaran bahwa siswa belum pernah mengikuti pembelajaran konsep reaksi redoks. Siswa belum dilibatkan pembelajaran yang melatihkan tahapan pembangunan konsep (menurut teori konstruktivis).

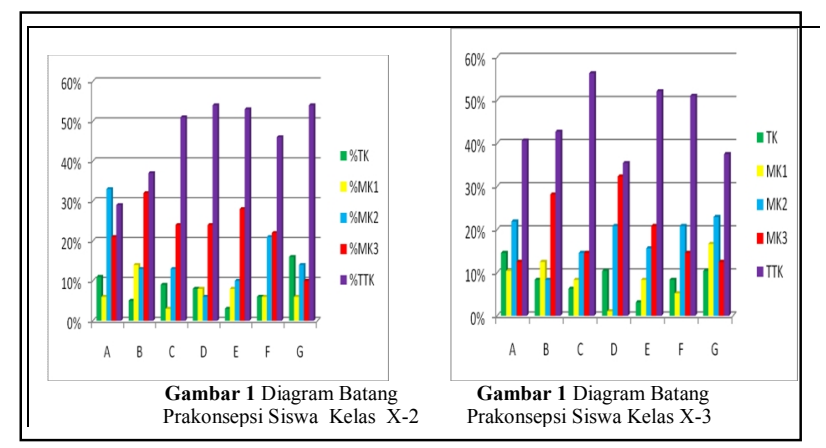

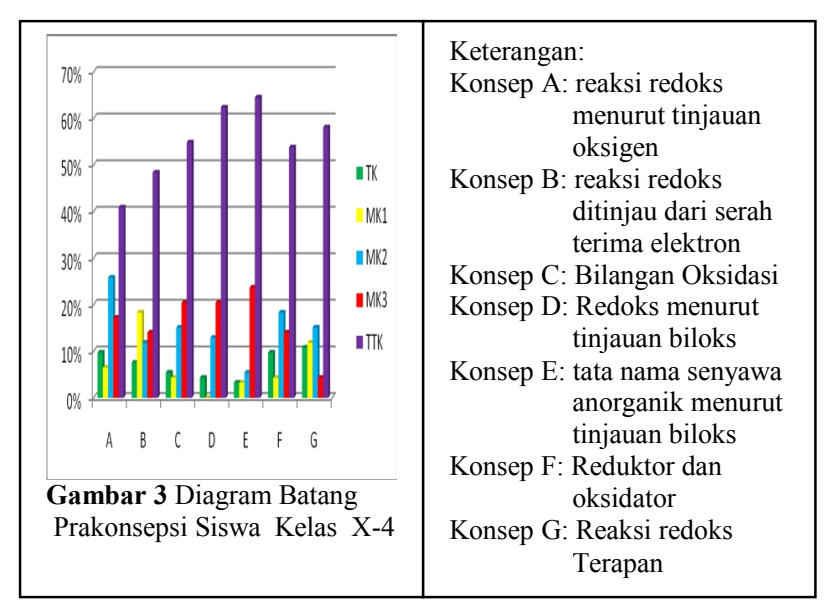

Ditemukan prakonsepsi siswa pada tingkatan MK1, MK2, atau MK3 yang menurut Suparno (2005) guru harus memberikan perhatian lebih pada individu-individu tersebut, sebab berpotensi menyebabkan terjadinya miskonsepsi dalam menerima konsep yang baru. Keberadaan yang wajar ditemukan siswa mempunyai konsepsi alternatif, hal ini sesuai dengan pendapat Ibrahim (2012) bahwa prakonsepsi (konsep awal) merupakan hasil pemahaman terhadap suatu fenomena alam, dalam pembahasan ini adalah reaksi redoks yang belum dipelajari secara formal di sekolah. Sebagian dari konsep awal pada diri siswa ada yang sesuai dengan konsep ilmiah, namun ada yang tidak sesuai dengan konsep ilmiah, yang disebut mempunyai konsepsi alternatif. Ketika pemahaman siswa atas konsep tertentu berbeda dengan konsep ilmiah, maka tidak boleh dihakimi sebagai miskonsepsi, namun dapat dinyatakan sebagai konsepsi altenatif. Hal ini sesuai dengan pendapat Horton (2004) bahwa istilah "miskonsepsi" tampaknya terlalu menghakimi dalam pandangan dari sifat tentatif dari ilmu pengetahuan dan fakta bahwa banyak dari konsepsi pada diri anak telah berguna bagi siswa di masa lalu. Sifat tentatif ilmu pengetahuan yang dimaksud di sini adalah kebenarannya dapat berubah jika ditemukan bukti lain yang lebih dipercaya secara ilmiah.

\section{B. Keterlaksanaan Sintaks Model Prevensi Dengan Learning Cycle 7E}

Keterlaksanaan pembelajaran di dalam penelitian ini diamati oleh dua orang pengamat. Aspek yang diamati terbagi ke dalam tiga bagian, yaitu: keterlaksanaan sintaks yang terskenariokan dalam RPP, aktivitas siswa, dan penilaian terhadap isian Lembar Kerja Siswa (LKS). Ratarata hasil pengamatan keterlaksanaan pembelajaran secara keseluruhan pada setiap kelas termasuk ke dalam kategori baik hingga sangat baik. Pelaksanaan pembelajaran prevensi dengan menerapkan model Learning Cycle 7E dilakukan tiga pertemuan untuk setiap kelas. Hasil uji Mann-Whitney yang membandingkan skor-skor penilain sintaks pada kedua pengamat dan 
untuk menilai kesamaan pandang pengamat terhadap pelaksanaan pembelajaran pada kelas X-2, X-3, dan X-4 pada setiap pertemuan diperoleh nilai $\mathrm{p}$-value $>0,05$. Artinya, tidak ada perbedaan signifikan sudut pandang kedua pengamat dalam mengamati keterlaksanaan pembelajaran. Untuk menguji keajegan guru mengajar pada setiap kelas dan setiap pertemuan dilakukan Uji Kruskal Wallis, dan pengajaran pada ketiga kelas diperoleh $p$-value $>0,05$, artinya guru mampu menjaga konsistensi kualitas dalam melaksanakan pembelajaran pada setiap pertemuan pada semua kelas penelitian. Komponen sintaks pembelajaran yang dinilai terdiri dari tujuh fase dari Learning Cycle 7E yang diawali dengan fase elicit, yang mengungkap konsep prasyarat siswa, dilanjutkan fase engage untuk menarik perhatian siswa dengan menghadirkan fenomena. Kegiatan inti dari model pembelajaran Learning Cycle 7E, berupa fase explore, explain, dan elaborate. Fase explore kegiatan belajar mengajar melibatkan siswa dalam merumuskan masalah/pertanyaan penelitian, menjawab pertanyaan penelitian, melakukan penyelidikan, organisasi data, analisis data, menarik simpulan. Pada fase explain siswa menjelaskan hasil kerja selama fase explore, dan pada fase elaborate guru mengajak siswa untuk menggunakan istilah umum untuk mengembangkan pengetahuan baru. Sebagai penutup pengajaran adalah fase evaluate dan extend (memperlihatkan hubungan dengan konsep lain dan penerapannya dalam kehidupan sehari-hari) (Eisenkraf, 2003).

Pengamatan terhadap aktivitas siswa dilakukan secara berkelompok. Hasil pengamatan aktivitas siswa yang merepresentasikan keterampilan psikomotorik, perilaku berkarakter, dan keterampilan sosial memperoleh kriteria penilaian baik hingga sangat baik di ketiga kelas penelitian. Hasil penilaian terhadap isian Lembar Kerja Siswa (LKS) hampir semua kelompok menunjukkan tanda-tanda kinerja yang positif pada komponen-komponen yang dinilai. Hal ini dapat diartikan bahwa skenario pembelajaran Learning Cycle 7E yang dibantu perangkat LKS telah berhasil mengkondisikan siswa untuk berlatih mengembangkan kognitif proses. Berkaitan dengan aktivitas siswa dalam pengerjaan LKS dan worksheet merupakan bagian dari kegiatan seperti seorang ilmuan yang bekerja dengan metode ilmiah.

Pengintegrasian aspek psikomotorik, sikap (karakter), dan keterampilan sosial ke dalam pembelajaran telah dilaksanakan guru dengan baik. Pengintegrasian aspek-aspek tersebut ke dalam proses pembelajaran akan mendukung penguasan konsep yang dibelajarkan. Hal ini sesuai dengan teori perkembangan Piaget mewakili konstruktivisme, yang memandang perkembangan kognitif sebagai suatu proses, anak secara aktif membangun sistem makna dan pemahaman realitas melalui pengalaman-pengalaman dari interaksi-interaksi yang dilakukan (Nur, 2008). Selanjutnya menurut Nur (2008) bahwa Vygotsky berpendapat seperti Piaget, belajar tidak terlepas dengan lingkungan, maka dalam belajar keduanya menyarankan untuk menggunakan kelompok belajar dengan anggota kelompok yang heterogen, sehingga memungkinkan adanya take and give dalam belajar.

\section{Konsepsi Siswa Sesudah Prevensi Miskonspsi Siswa}

Pembelajaran dengan model pembelajaran Learning Cycle yang dilakukan untuk mencegah terjadinya miskonsepsi siswa. Profil konsepsi siswa setelah pembelajaran menunjukkan bahwa bahwa pembelajaran dengan Learning Cycle 7E menunjukkan ada peningkatan siswa mengarah ke tahu konsep, namun masih menyisakan banyak beban siswa pada MK1, MK2, dan MK3. Sebagian besar siswa masih bertahan pada status prakonsepsinya. Pendapat ini diperkuat Ibrahim (2012) yang menyatakan bahwa walaupun konsep yang benar telah diperkenalkan kepada siswa, masih terdapat peluang kembali kepada prakonsepsinya sendiri yang salah (miskonsepsi).

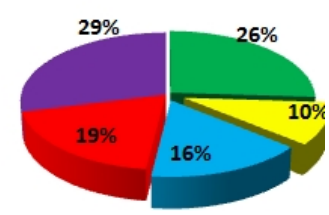

Gambar 4. Diagram Paste Konsepsi Siswa Kelas X2 Setelah Pembelajaran Prevensi

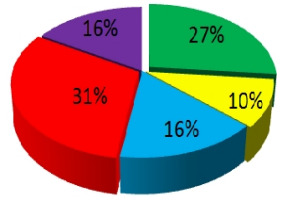

Gambar 6. Diagram Pastel Konsepsi Siswa Kelas X-4 Setelah Pembelajaran Prevensi

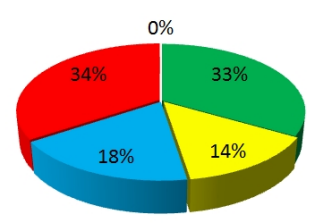

Gambar 5. Diagram Pastel Konsepsi Siswa Kelas X3 Setelah Pembelajaran Prevensi
Sesuai dengan teori Piaget (di dalam Suparno, 2000) bahwa siswa yang mempunyai prakonsepsi tidak dapat mengasimilasikan pengalaman yang baru dengan skema yang dimiliki siswa, karena pengalaman yang baru tidak sesuai dengan skema yang ada. Pada keadaan yang demikian siswa akan melakukan akomodasi. Jika dibandingkan pada ketiga kelas tersebut, pada kelas X-2, justru yang dominan adalah siswa yang tidak tahu konsep (TTK), hal ini memberikan gambaran bahwa konsep reaksi redoks belum dipahami oleh siswa.

Jika ditinjau dari keterlaksanaan pembelajaran dengan penerapan Learning Cycle 7E kegiatan belajar terlaksana dengan sangat baik dan siswa pun 
menjalankan aktivitas belajar sesuai dengan fase-fase Model Learning Cycle 7E. Hal yang agak aneh terlihat bahwa profil konsepsi siswa pada kelas X-2 dominan siswa tidak tahu konsep, berbeda dengan X-3 yang sedikit sekali ditemukan siswa berstatus TTK. Siswa yang berstatus TTK juga banyak ditemukan di kelas X-4, namun tidak sebanyak pada kelas X-2. Hal ini sesuai dengan hasil pengamatan dari kedua pengamat bahwa pada kelas X-2 ada kekurangan waktu yang lebih banyak dibandingkan siswa pada kedua kelas lainnya. Karena siswa kurang waktu dalam memahami konsep reaksi redoks sehingga pada saat mengerjakan post-test I pada kedua kelas, yaitu kelas X-2 dan X-4 banyak yang memilih "tidak yakin" pada tier-3, sehingga banyak ditemukan siswa berstatus TTK. Melalui angket siswa, diperoleh pendapat siswa bahwa pemahaman konsep reaksi redoks perlu waktu yang cukup agar dapat memahaminya dengan baik. Sebagian kecil siswa merasa pengajaran guru terlalu cepat, siswa belum menguasai benar konsep pada petemuan sebelumnya, sudah dilanjutkan ke materi berikutnya. Apalagi bahwa siswa terbiasa dengan pembelajaran yang berpusat pada guru yang dibawa siswa sejak masih belajar di SMP, sehingga ketika siswa dilibatkan dalam pembelajaran yang berpusat pada siswa seperti Learning Cycle 7E maka dirasakan berat bagi siswa. Hal ini sesuai dengan kelemahan pembelajaran dengan Learning Cycle 7E bahwa waktu yang dibutuhkan lebih lama, karena siswa diajak untuk dapat mengeksplorasi pengetahuannya sendiri (Budiasih, 2003).

Pemahaman konsep siswa memerlukan proses. Piaget (di dalam Dahar, 1988) menjelaskan bahwa tahap perkembangan kemampuan kognitif anak, mulai dari tahap sensori motorik (konkret) sampai tahap formal/abstrak. Pada tahap perkembangan dari konkret menjadi abstrak inilah peserta didik banyak mengalami miskonsepsi disebabkan terbatasnya kemampuan mengkonstruksi pengetahuan dan tidak lengkapnya pengetahuan yang dimiliki sebagai bekal mengkonstruksi suatu konsep secara tepat dan benar. Secara perlahan sesuai dengan tahap perkembangannya, mereka akan terus-menerus memperbaiki dan mengurangi miskonsepsi dalam dirinya hingga akhirnya diperoleh pemahaman yang benar tentang konsep tertentu. Sebagai bahan pertimbangan, menurut Miller et al. (di dalam Dazhi and Inanc S., 2013) bahwa prevensi miskonsepsi dengan pembelajaran berbasis inkuiri tidak berhasil dilakukan di sekolah tingkat SLTP dan SLTA), dan baru berhasil pada tingkat universitas.

\section{Hasil Belajar Siswa Setelah Pembelajaran dengan Learning Cycle 7E}

Secara deskriptif dengan standar ketuntasan $\mathrm{KD}=$ 70, maka pada kelas X-2 hanya satu siswa yang tuntas. Pada kelas X-3 terdapat dua siswa yang tuntas, sedangkan pada kelas X-4 belum ada satu orang pun yang tuntas. Pembelajaran konsep reaksi redoks menggunakan Learning Cycle 7E belum mampu menghantarkan siswa mencapai ketuntasan baik secara individual maupun klasikal. Secara klasikal berarti siswa yang tuntas di kelas di atas 75\%. Hal ini sangat mungkin disebabkan oleh rendahnya tingkat prakonsepsi dan kemampuan prasyarat yang dimiliki siswa. Hal ini sesuai dengan penghitungan sumber-sumber miskonsepsi siswa yang diuraikan di subbab berikutnya yang diperoleh simpulan prakonsepsi merupakan sumber miskonsepsi terbesar dan disusul oleh kemampuan prasyarat di antara 3 faktor yang dihimpun datanya.

Secara inferensial pembelajaran dengan model Learning Cycle 7E berdampak positip dalam peningkatan hasil belajar siswa secara signifikan dengan tingkat kepercayaan 95\%, namun jika ditinjau dari ketuntasan belajar model Learning Cycle 7E belum menunjukkan ada keberhasilan.

Jika melihat kembali pada amanat Permendikanas nomor 22 tahun 2006, bahwa pengajaran di kelas adalah harus berbasis inkuiri, pembelajaran harus dihadapkan langsung dengan fenomena alam, bersifat induktif, pembelajaran dengan Learning Cycle 7E tetap dilanjutkan walaupun belum berhasil jika ditinjau dari ketuntasan belajar. Perlu adanya tahapan refleksi pada pembelajaran baik sisi dari guru maupun siswa. Guru perlu merefleksikan bagaimana respon siswa terhadap materi yang dibawakan dengan menggunakan model Learning Cycle 7E dan dari sisi siswa bagaimana kegiatan tindak lanjut pembelajaran siswa masing-masing di rumah dilakukan atau tidak. Jika belajar hanya mengandalkan pertemuan di kelas, maka konsep yang seharusnya harus direview lagi di rumah dan latihan soal pun tidak banyak dikerjakan. Materi redoks di kelas X banyak konsep yang perlu latihan soal, seperti pada penentuan bilangan oksidasi.

Menurut Carrol dan Block (di dalam Ischak dan Warji, 1987) bahwa tidak semua siswa mempunyai kecepatan yang sama dalam memahami konsep-konsep tersebut, hal ini erat sekali hubungan antara tingkat penguasaan belajar siswa dengan waktu yang disediakan dan yang digunakan sungguh-sungguh oleh siswa tersebut. Terkait dengan waktu yang berbeda-beda yang diperlukan siswa untuk memahami suatu konsep, maka dimungkinkan karakteristik siswa berpengaruh terhadap kecepatan siswa dalam pemahaman konsep. Berkaitan dengan belum tercapainya ketuntasan hampir semua siswa pada ketiga kelas, maka sangat perlu disiapkan pengajaran remedial. 


\section{E. Faktor Penyebab Miskonsepsi Siswa pada Konsep Reaksi}

Masih berdasarkan pada pemetaan konsepsi siswa setelah dilakukan pembelajaran prevensi dengan Learing Cycle 7E, ternyata siswa masih banyak mengalami miskonsepsi dan sebagian lagi tidak tahu konsep, maka peneliti meminta siswa untuk mengisi angket terkait kesulitan belajar yang dialami yang berpotensi melahirkan miskonsepsi dan tidak tahu konsep pada diri siswa. Sangatlah sulit mengamati pemikiran siswa dalam memahami suatu konsep, walaupun kegiatan pembelajaran telah berjalan dengan baik, namun setelah diberikan tes ternyata masih banyak ditemukan siswa yang mengalami miskonsepsi.

Menurut Suparno (2005) banyak kemungkinan faktor-faktor yang menyebabkan terjadinya miskonsepsi, secara garis besar penyebabnya adalah siswa, guru/pengajar, buku teks, konteks, dan cara mengajar guru. Faktor-faktor tersebut masih ada jabarannya lebih banyak lagi. Sebagai upaya memperkuat pembahasan terhadap hasil-hasil penelitian, maka peneliti mempertimbangkan perlunya diungkap faktor-faktor penyebab terjadinya miskonsepsi pada siswa berdasarkan pada respon siswa setelah pembelajaran prevensi dilakukan dan kemungkinan adanya faktor-faktor yang menyebabkan kesulitan dalam memahami redoks pada khususnya dan ilmu kimia pada umumnya. Data-data yang mungkin disimpulkan sebagai faktor-faktor miskonsepsi dikumpulkan berdasarkan pre-test konsep prasyarat redoks, pre-test pemahaman konsep redoks, dan berdasarkan angket yang diberikan kepada siswa.

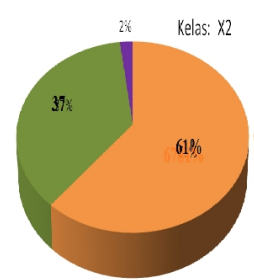

(a)

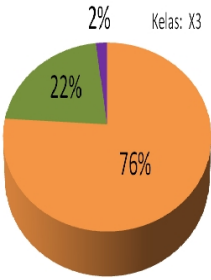

(b)

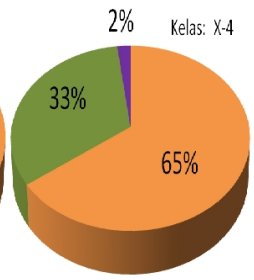

(c)
- Prakonsepsi Prasyarat @ Cara Mengajar Guru

Gambar 4 Diagram Pastel Faktor-faktor Penyebab Miskonsepsi pada Kelas X-2 (a), X-3 (b), dan X-4 (c)

Bahwa pada kelas X-2, X-3, dan X-4 dapat ditarik simpulan bahwa di antara tiga faktor penyebab miskonsepsi yang diidentifikasi intensitasnya, maka faktor terbesar adalah prakonsepsi, diikuti konsep prasyarat, dan cara mengajar guru. Urutan tersebut berlaku pada semua kelas yang diteliti, kelas X-2, X-3, dan X-4.

Keberadaan prakonsepsi siswa dan kemampuan prasyarat penting bagi siswa, karena keduanya merupakan batu loncatan untuk mencapai suatu pemahaman konsep tertentu. Ditinjau dari hirarki belajar dari Gagne et al., (1988) konsep awal sangat membantu dalam pembentukan struktur kognitif berikutnya, tetapi mengapa menjadi sumber miskonsepsi. Hal ini sama halnya air sangat bermanfaat bagi manusia, bahkan PDAM (perusahaan air minum daerah) mempunyai motto "Setetes air adalah kehidupan", tetapi banyak juga kerugian karena air. Petani gagal panen karena menjelang panen, padinya kebanjiran, dan banyak kerugian lainnya akibat banjir. Jadi air mempunyai sisi positip sebagai sumber kehidupan, namun kebalikannya menjadi sisi negatif kalau jumlahnya berlebihan (banjir). Sama halnya prakonsepsi dan konsep prasyarat bermanfaat pada pembelajaran berikutnya jika penguasaan keduanya adalah benar, namun jika salah malahan menyulitkan untuk pemahaman konsep berikutnya (Gagne et al., 1988). Menurut Horton (2004) dari konsep awal yang tidak sesuai dengan konsep ilmiah malahan menyulitkan kepada pemahaman berikutnya dan yang menjadikan siswa mengalami miskonsepsi. Hal ini juga dibenarkan oleh Ibrahim (2012) bahwa dengan konsep awal dan prakonsepsi siswa yang salah akan menyebabkan miskonsepsi. Berdasarkan hal tersebut, maka perlu kewaspadaan dari guru, jika prakonsepsi siswa banyak yang mengarah ke miskonsepsi siswa maka guru perlu hati-hati dan senantiasa mengikuti pemikiran siswa, namun selalu mengarahkan untuk menuju status tahu konsep.

Terkait pada cara mengajar guru sebagai faktor penyebab miskonsepsi adalah di antara siswa merasa guru yang menyebabkan siswa kurang memahami konsep yang dipelajari, beralasan guru terlalu cepat dalam mengajar. Ditinjau dari penguasaan konsep guru, tidak ada jawaban siswa yang mengarah pada alasan tersebut. Namun jika ditarik simpulan sebenarnya, karena siswa tersebut kurang waktu dalam memahami suatu konsep. Dengan demikian faktor cara mengajar guru tidak dominan faktor terjadinya miskonsepsi dalam penelitian ini, namun yang lebih besar adalah faktor prakonsepsi siswa.

\section{PENUTUP}

\section{Simpulan}

Tindakan pembelajaran prevensi untuk meminimalisasi terjadinya miskonsepsi siswa pada konsep reaksi oksidasi reduksi di SMA Negeri Model Terpadu Bojonegoro menggunakan model pembelajaran Learning Cycle 7E menghasilkan simpulan sebagai berikut: (1) tindakan prevensi yang dilakukan telah berhasil meningkatkan proporsi pemahaman siswa, namun masih menyisakan jumlah besar beban miskonsepsi dalam pada siswa, (2) pembelajaran konsep reaksi redoks dengan model Learning Cycle 7E yang digunakan untuk memprevensi miskonsepsi berdampak 
signifikan terhadap perubahan hasil belajar siswa, walau belum berdampak kepada pencapaian ketuntasan individual maupun klasikal.

\section{Saran}

a. Sebelum memasuki pembelajaran guru sangat perlu untuk mengadakan pretest untuk mengungkap prakonsepsi siswa dan profil konsep prasyarat.

b. Sebaiknya guru mengungkap profil konsepsi siswa setelah berakhir pembelajaran dan dapat menggunakan three tier diagnostic test ini dan merancang tes serupa sesuai dengan pokok bahasan yang diajarkan sebagai bahan refleksi dan perbaikan pada pembelajaran konsep berikutnya.

c. Berdasarkan pada hasil penelitian yang menunjukkan bahwa walaupun pembelajaran dilaksanakan dengan berbasis inkuiri masih menyisakan banyak beban miskonsepsi dan sebagaian besar siswa belum mencapai tingkat ketuntasan, maka sangat dipandang perlu untuk merencanakan pembelajaran remedial untuk mereduksi beban miskonsepsi siswa dan mengantarkan siswa untuk mencapai ketuntasan belajar pada konsep yang dipelajarinya.

\section{DAFTAR PUSTAKA}

Amien, Moh. 1988. Buku Pedoman Laboratorium dan Petunjuk Praktikum Pendidikan IPA Umum (General Science) untuk Lembaga Pendidikan Tenaga Pendidikan. Jakarta: Departemen Pedidikan dan Kebudayaan Direktorat Jenderal Pendidikan Tinggi.

Arslan, H.O., Cigdemoglu, C., and Moseley, C. 2012. A Three-Tier Diagnostic Test to Assess Pre-Service Teachers' Misconceptions about Global Warming, Greenhouse Effect, Ozone Layer Depletion, and Acid Rain.Turkey: Education International Journal of Science Education, 34(11),1667-1686.

Barthlow, Michelle J. 2011. The Effectiveness of Process Oriented Guided Inquiry Learning to Reduce Alternate Conceptions in Secondary Chemistry. Dissertation. Liberty University.

Budiasih, E., Widarti, H.R. 2004. Penerapan Pendekatan Daur Belajar (Learning Cycle) dalam Pembelajaran Matakuliah Praktikum Kimia Analisis Instrumen. Jurnal Pendidikan dan pembelajaran Vol 10 (1), hal 70-78.

Dazhi and Inanc. S. 2013. The Search For Starategiies to Prevent Persisten Misconception. Atlanta: ASEE Annual Conference Exposition.

Depdiknas. 2006. Silabus Mata Pelajaran Kimia. Direktorat Pembinaan SMA. Jakarta: Direktorat Jendral Pendidikan Dasar dan Menengah.

Eisenkraft Arthur. 2003. Expanding the 5E Model. The Science Teacher Volume 70 N0.6. New York: National Science Teachers Accosiation.
Gagne, Robert M, Leslie J. Brigs and Walter W. Wager. 1988. Principles of Instructional Design. Florida. Holt, Rinehart and Winston. Inc.

Horton, Christopher. 2004. "Student Alternatif Conceptions in Chemistry". Journal of Science Education 7(2): 2 (2004)

Ibrahim, Muslimin. 2012. Konsep Miskonsepsi dan Cara Mengatasinya. Surabaya: Unesa University Press.

Ischak S.W. dan Warji R. 1987. Program Remedial dalam Proses Belajar Mengajar. Yogyakarta: Liberty.

Nakhleh, M.B. 1992. "Why Some Student Don't Learn Chemistry (Chemical Miscoception)". International Journal of Chemical Education, 69: 191-196.

Nur, Muhammad. 2008. Teori-teori Pembelajaran Kognitif. Surabaya: Unesa Press.

Polyiem, T., Nuangchalerm, P., and Wongchantra, P. (2011)." Learning Achievement, Science Prosess Sklls, and Moral Reasoning of Ninth Grade Students Learned by Learning Cycle and Socioscientific Issue-based Learning". Australia: Australian Journal of Basic and Aplied Sciences, 5 (10): 257-564.

Sumarni, W. 2010. Penerapan Learning Cycle Approuch Sebagai Upaya Meminimalisasi Miskonsepsi Mahasiswa pada Materi Struktur Molekul. Semarang: Universitas Negeri Semarang.

Suliman Wahid. 2002. Statistik Non Parametrik Contoh Kasus dan Pemecahannya dengan SPSS. Yogyakarta: Penerbit Andi.

Suparno, Paul. 2000. Teori Perkembangan Kognitif Jean Piaget. Yogyakarta: Kanisius.

Suparno, Paul. 2005. Miskonsepsi \& Perubahan Konsep Pendidikan Fisika. Jakarta: PT.Grasindo.

Wahyuningrum, S., dan Suyono. 2013. "Pola Pergeseran Konsepsi Siswa pada Struktur Atom setelah Pembelajaran dengan Strategi POGIL." Surabaya: UNESA Journal of Chemical Education, 2(1), 4350.

Yunianingsih, W, dan Suyono. 2013. "Tingkat Keterampilan Berpikir Siswa Saling Bergantung (Dependen) dengan Tingkat Penguasaan Konsep Siswa." Surabaya: UNESA Journal of Chemical Education, 2(1), 1-10. 